\title{
Assessing the risks of non-target feeding by the accidentally introduced ragweed leaf beetle, Ophraella communa, to native European plant species
}

\author{
Benno Andreas Augustinus ${ }^{\mathrm{a}, \mathrm{b}, *}$, Rodolfo Gentili ${ }^{\mathrm{c}}$, David Horvath ${ }^{\mathrm{a}}$, Ruhollah Naderi ${ }^{\mathrm{d}}$, Yan Sun ${ }^{\mathrm{a}}$, \\ Anne-Marth Truce Eleonoor Tournet ${ }^{\mathrm{a}}$, Urs Schaffner ${ }^{\mathrm{b}}$, Heinz Müller-Schärer ${ }^{\mathrm{a}}$ \\ ${ }^{a}$ University of Fribourg, Department of Biology, 1700 Fribourg, Switzerland \\ ${ }^{\mathrm{b}} \mathrm{CABI}, 2800$ Delémont, Switzerland \\ ${ }^{\mathrm{c}}$ Dipartimento di Scienze dell'Ambiente e della Terra, Università di Milano-Bicocca, 20126 Milano, Italy \\ ${ }^{\mathrm{d}}$ Department of Crop Production \& Plant Breeding, School of Agriculture, Shiraz University, Shiraz, Iran
}

\section{A R T I C L E I N F O}

\section{Keywords:}

Accidental introductions

Ambrosia artemisiifolia

Biosafety

Host range

Post-release evaluation

\begin{abstract}
A B S T R A C T
In 2013, the North American oligophagous leaf beetle, Ophraella communa LeSage (Coleoptera: Chrysomelidae), was found in Europe for the first time. Recent studies in Northern Italy and Southern Switzerland record extensive defoliation by O. communa on its preferred host, common ragweed, Ambrosia artemisiifolia L. (Asteraceae, Tribe Heliantheae), and reductions in its flowering and seeding. In some regions in Northern Italy, this has reportedly led to a $>80 \%$ depletion in airborne $A$. artemisiifolia pollen concentrations. The potential for nontarget damage by $O$. communa to closely related native European plant species was previously unknown. During extensive field surveys covering 18 populations of nine potential non-target species, we found adult $O$. communa on a single plant individual. In a common garden field experiment in Northern Italy in an area with high $O$. communa densities, leaf damage was highest on two other Asteraceae species, Dittrichia graveolens (L.) Greuter and Pentanema helveticum (Weber) D.Gut.Larr. (both in the Tribe Inuleae). While adult feeding was observed on most of the test plant species, only $D$. graveolens, which has recently extended its range and is now an invasive species in Western Europe, sustained all life stages of $O$. communa in the common garden and in laboratory experiments. We found no evidence of substantial non-target effects by $O$. communa that could potentially threaten populations of European native plant species that are taxonomically closely related to ragweed.
\end{abstract}

\section{Introduction}

The rate of biological invasions has substantially increased over the past 200 years and the present rate of new introductions is expected to continue (Seebens et al., 2017). Invasive alien plant species can cause devastating impacts on ecosystems and ecosystem services (Vilà et al., 2011). With new introductions of invasive weed species, accidental introductions of their natural enemies are also expected to increase: such introductions are already a relatively common phenomenon, with some positive outcomes (Fand et al., 2013; Shaw et al., 2018). For example, the accidentally introduced weevil Stenopelmus rufinasus Gyllenhal (Coleoptera: Erirhinidae) has controlled water fern, Azolla filiculoides Lam., populations in Great Britain (Bacon et al., 2018), and the cochineal insect Dactylopius opuntiae (Cockerell) (Hemiptera: Coccoidea: Dactylopiidae) has suppressed the invasive cactus, Opuntia ficusindica (L.) Mill., in Spain (Shaw et al., 2016).

While accidental introductions of natural enemies of invasive weeds may result in successful control of the target weed, they bear the risk of non-target effects on taxonomically closely related crops, ornamental plants, or native species. A crucial first step in a classical biological control programme is the assessment of the candidate's host specificity (Müller-Schärer and Schaffner, 2008). In pre-release studies, native and economically important plant species are selected for host range testing based on the centrifugal phylogenetic hypothesis (Wapshere, 1974), which posits that the likelihood that a non-target species will be attacked by a biological control agent decreases with increasing phylogenetic distance between the non-target and the target species. After selecting suitable plant species, host range tests are conducted to assess whether the plants are within the fundamental or realized host range of the potential biological control agent. The fundamental host range is the range of plants on which the biological control agent can complete its life cycle. The realized host range is the range of hosts that are attacked under natural conditions and tends to be considerably narrower than the fundamental host range (Fowler et al., 2012; Schaffner et al.,

\footnotetext{
* Corresponding author at: CABI, Rue des Grillons 1, 2800 Delémont, Switzerland.

E-mail address: benno.augustinus@gmail.com (B.A. Augustinus).
} 
2018). In classical biological control of weeds, potential biological control agents whose fundamental host range includes native or economically important species are often not approved for field release. This conservative approach is one explanation of why significant nontarget attack by deliberately introduced classical biological control agents of weeds is rare (Hinz et al., 2019).

The ragweed leaf beetle, Ophraella communa LeSage (Coleoptera: Chrysomelidae), is an oligophagous insect native to North America. It preferentially feeds on common ragweed, Ambrosia artemisiifolia L. (Asteraceae), which is also native to North America and invasive in different parts of the world, including Australia, Asia and Europe (Montagnani et al., 2017). In Europe, it is a noxious agricultural weed with a wide distribution mainly in central and Eastern Europe (Bullock et al., 2012; Gentili et al., 2017; Kazinczi et al., 2009; Skjøth et al., 2019), resulting in significant economic losses in agricultural systems (Kazinczi et al., 2008; Kómives et al., 2006). Moreover, this monoecious and wind-pollinated plant is of concern due to its highly allergenic pollen, which causes serious health problems and costs in the invaded range (Essl et al., 2015; Müller-Schärer et al., 2018; Schaffner et al., 2020).

Ophraella communa was declared as not safe for deliberate release in Australia after it was shown to be able to complete its life cycle on sunflower under laboratory conditions (Palmer and Goeden, 1991). However, it was detected in Japan and Taiwan in 1996 (Wang and Chiang, 1998; Takizawa, 1999), probably due to accidental introductions, and subsequently in South Korea (Sohn et al., 2002) and China (Meng et al., 2007). In China, the beetle was first reported in 2001. A wide range of subsequent laboratory and field experiments, as well as field surveys, did not find significant non-target effects by $O$. communa on sunflower (Zhou et al., 2011). Since then, the beetle has been massreared and mass-released for the biological control of A. artemisiifolia in various locations (Guo et al., 2011; Zhou et al., 2017) and has become widely distributed in China (Sun et al., 2017).

More recently, $O$. communa was accidentally introduced into Europe, where it was first found in Northern Italy and Southern Switzerland in 2013 (Müller-Schärer et al., 2014). The beetle spread across Northern Italy (Augustinus et al., 2015; Lommen et al., 2017) and reached Croatia in 2018 (Zadravec et al., 2019). It has been found in high densities in Northern Italy, defoliating the host plant and reducing flower and seed production, where aerial $A$. artemisiifolia pollen concentrations in some regions have dropped by $80 \%$, a change that could not be explained by meteorological data or land-use changes (Bonini et al., 2015a, 2015b). Projections of the potential range and abundance of $O$. communa suggest that it could reach population densities comparable to those in Italy in other parts of Europe, particularly on the Balkan Peninsula (Supplementary Fig. 1, Augustinus et al., 2020). The potential economic benefits of $A$. artemisiifolia control by $O$. communa in Europe are likely to be considerable (Mouttet et al., 2018; Schaffner et al., 2020).

Preliminary studies indicate that $O$. communa does not pose a substantial risk to sunflower or to ornamentals (Müller-Schärer et al., 2017). However, O. communa has not yet been submitted to careful host range screening with native European plant species. Thus, there is a need to evaluate its biosafety in Europe to accurately balance the benefits reported so far with the potential risks that could be caused by this accidentally introduced biological control agent. In this paper we report on a two-year field survey, a common-garden experiment and laboratory studies to assess the likelihood of a non-target attack on native European plant species, with a focus on rare and endangered plant species closely related to $A$. artemisiifolia.

\section{Material and methods}

\subsection{Study organisms}

Ambrosia artemisiifolia is an annual Asteraceae, which has invaded ranges in every continent except Antarctica (Essl et al., 2015; Montagnani et al., 2017). This predominantly outcrossed plant produces racemes with flowerheads containing flowers that produce highly allergenic pollen, causing allergic rhinitis and severe asthma (Thibaudon et al., 2010), which result in high medical costs and reduction in quality of life among the allergic population. Estimates from one region (Rhônes-Alpes) in southern France amounted to $€$ 5-7 million per year (Mouttet et al., 2018) and estimates for health care reductions in Europe are projected to exceed $€ 1.1$ billion per year once the beetle has exploited its full range (Schaffner et al., 2020).

Ambrosia artemisiifolia plants are highly prolific seed producers, and seeds remain viable in the ground for more than 40 years (Toole and Brown, 1946). In Northern Italy, the first seedlings emerge in early April, but the germination period is protracted (Kazinczi et al., 2008) and germination rates are variable (Fogliatto et al., 2019). Plants release pollen in August and September (Bonini et al., 2015a) and produce seeds from mid- to late-September (Lommen et al., 2018). Ophraella communa is a multivoltine, oligophagous herbivore which can achieve up to seven generations per year in its introduced range in southern China (Zhou et al., 2014) and up to four generations in Europe (Mouttet et al., 2018). The leaf beetle overwinters in the adult stage and, in Europe, the first eggs are found in spring as soon as A. artemisiifolia seedlings emerge (Bosio et al., 2014). The females lay eggs in batches of 10-60 eggs, and the three larval stages and the highly mobile adults feed on the green parts of their host plant (Müller-Schärer et al., 2014).

To gain an overview of host species known to date, we searched via Google Scholar for "Ophraella communa" AND 'host', resulting in 633 hits. We followed the list of publications according to their apparent relevance to our study. Papers, including host species already investigated by studies already on the list, were not included if they did not use a novel method or technique (laboratory or field, choice or no choice experiments). We only included plant species for which both larval and adult $O$. communa feeding was reported, since the highly mobile larvae and adults can be found on plants far beyond their host range, and scoring these incidental observations would overpredict both the ecological and fundamental host range of the beetle.

We focused on native plant species present in Northern Italy (i.e., the Lombardy Region) and in Southern Switzerland that belong to the tribes Coreopsideae and Inuleae and from which populations were found $<6 \mathrm{~km}$ away from A. artemisiifolia and O. communa populations. These tribes are the most closely related taxa to the tribe Heliantheae (sunflowers): the latter has no native species in the study region. For the laboratory experiments, we included two species (Pentanema britannicum L. and Pentanema helveticum (Weber) D.Gut.Larr.) that were not found in the study area, but could be at risk if the beetle will cross the Alps. We also considered Centaurea nigrescens Willd., a more distantly related plant species from the tribe Cardueae, as adult $O$. communa feeding was observed in the field on this plant species in summer 2015 (B. Augustinus, pers. obs.). In total, we included ten native plant species in our study. Of these, according to the Red List of Switzerland and based on the IUCN categories and criteria at the regional level (Bornand, 2016) (Table 1), one species is categorized as near threatened (NT), two species as vulnerable (VU) and four species as endangered (EN). Some of these are also included in the list of species protected in the Lombardy Region (Regione Lombardia, 2010). In addition, we selected one species native to Southern Europe and Northern Africa, Dittrichia graveolens (L.) Greuter, and the North American species Bidens frondosa L., which is naturalized in the study region, to increase the number of representatives of the Coreopsideae tribe (Table 1). To illustrate the relationship between the test plant species to A. artemisiifolia, we constructed a phylogenetic tree using iTOL (interactive tree of life) v4 (Letunic and Bork, 2019) (Supplementary Fig. 2). 
Table 1

Plant species examined in this study.

\begin{tabular}{|c|c|c|c|c|c|c|c|}
\hline Tribe & Name & EPPO code & State of threat & Field survey & Common garden field & Laboratory & Flowering time in month \\
\hline Heliantheae & Ambrosia artemisiifolia $\mathrm{L}$. & Ambar & NP & $\mathrm{X}$ & $\mathrm{X}$ & & $8-10$ \\
\hline Coreopsideae & Bidens cernua L. * & Bidce & VU & $\mathrm{x}$ & & & 7-9 \\
\hline Coreopsideae & Bidens frondosa $\mathrm{L}^{\mathrm{a}}$ & Bidfr & NP & $\mathrm{x}$ & & & $8-10$ \\
\hline Inuleae & Carpesium cernuum L. & Carce & $\mathrm{EN}$ & $\mathrm{x}$ & & & $7-8$ \\
\hline Inuleae & Dittrichia graveolens (L.) Greuter b & Ditgr & NP & & $\mathrm{X}$ & $\mathrm{X}$ & $8-11$ \\
\hline Inuleae & $\begin{array}{l}\text { Pentanema britannicum (L.) D.Gutt.Larr.(Inula } \\
\text { britannica) }\end{array}$ & Penbr & EN & & $\mathrm{x}$ & $\mathrm{X}$ & $7-9$ \\
\hline Inuleae & Pentanema conyzae (DC.) D.Gut.Larr. (Inula conyzae) & Penco & LC & $\mathrm{x}$ & $\mathrm{x}$ & $\mathrm{X}$ & $7-10$ \\
\hline Inuleae & $\begin{array}{l}\text { Pentanema helveticum (Weber) D.Gut.Larr. (Inula } \\
\text { helvetica) }\end{array}$ & Penhe & VU & & $\mathrm{x}$ & $\mathrm{X}$ & $7-9$ \\
\hline Inuleae & Pentanema hirtum (L.) D.Gut.Larr. (Inula hirta) & Penhi & EN & $\mathrm{X}$ & $\mathrm{X}$ & $\mathrm{X}$ & $6-7$ \\
\hline Inuleae & Pentanema salicinum (L.) D.Gut.Larr. (Inula salicina) & Pensa & NT & $\mathrm{x}$ & $\mathrm{x}$ & $\mathrm{X}$ & $6-9$ \\
\hline Inuleae & $\begin{array}{l}\text { Pentanema spiraeifolium (L.) D.Gut.Larr. (Inula } \\
\text { spiraeifolia) }\end{array}$ & Pensp & EN & $\mathrm{X}$ & & & $7-10$ \\
\hline Inuleae & Xerolekia speciosissima (L.) Anderb * / ** & Xersp & $\mathrm{NE}$ & $\mathrm{x}$ & & & $7-8$ \\
\hline Cardueae & Centaurea nigrescens Willd. $^{\mathrm{b}}$ & Cenni & LC & $\mathrm{x}$ & $\mathrm{X}$ & $\mathrm{X}$ & $6-8$ \\
\hline
\end{tabular}

Plant species studied for potential non-target effect of Ophraella communa feeding, ordered in phylogenetic relationship to Ambrosia artemisiifolia (cf. Supplementary Fig. 2). State of threat is according to the "Red List of Vascular Plants" of the Swiss Federal Office for the Environment (NP = neophyte, LC = least concern, $\mathrm{NT}=$ near threatened, $\mathrm{VU}=$ vulnerable, $\mathrm{EN}=$ endangered, $\mathrm{NE}=$ not evaluated) (Bornand, 2016). * = species under legal protection (Regione Lombardia, 2010); $* *=$ endemic species in Northern Italy. ${ }^{a}$ : plant species selected to increase the number of representatives of the Coreopsideae tribe. ${ }^{\mathrm{b}}$ : selected because feeding was observed in the field.

\subsection{Field survey}

Because the accidentally introduced $O$. communa has established in a region where several native plant species related to the target weed occur naturally, we conducted a field survey to assess the levels of nontarget effects by this biological control agent under field conditions. We referred to 'info flora' (https://www.infoflora.ch/en/), and received advice from local botanists, to locate populations of the selected nontarget species in Southern Switzerland. We selected plant populations that were close to field sites $(<6 \mathrm{~km}$; Supplementary Fig. 3 and Supplementary Table 1) with observations of $A$. artemisiifolia and $O$. communa made between 2013 and 2015. In 2016 and 2017, we visited five sites in Southern Switzerland and found a total of ten populations of three native endangered species, two populations of two native species of least concern (Bornand, 2016; Info flora) and one population of $B$. frondosa (Table 1). We also surveyed eight populations with three additional plant species (a species endemic to Italy, and two species protected by law) in the Lombardy region in Italy (Table 1, Supplementary Tables 1 and 2). Additionally, we surveyed five populations of $A$. artemisiifolia that were near surveyed plant populations to confirm whether $O$. communa was present.

We monitored all selected plant populations between the end of June and the beginning of August, i.e., during peak abundance of $O$. communa. For plant populations of less than 50 individuals, we checked all plants for the presence of $O$. communa eggs, larvae and adults. For plant populations with more than 50 individuals, we divided the site into four equal sectors and sampled 50 plants per site, with at least 10 plants sampled in each of the four sectors. Where possible, we sampled individual plants at a minimum distance of $1 \mathrm{~m}$ from each other. If the population density of the plants was high enough, we achieved this by walking through the sectors in straight transects, choosing plants along the transect. We searched every leaf of the selected plants for $O$. communa presence. Leaf damage without any sign of $O$. communa was recorded as 'no damage by $O$. communa', since the plants surveyed typically also had native herbivores feeding on them.

\subsection{Common garden field experiment}

Plants for the common garden experiment and the laboratory experiments (see below) were grown from seeds (for the origin of the seed material, see Supplementary Table 3). The seeds were germinated on blotting paper in Petri dishes at day/night temperatures of $26 / 18^{\circ} \mathrm{C}$, a photoperiod of L:D 16:8 hr and relative humidity between 50 and 70\%. Seedlings were first transplanted into seed trays and then, when the plants were $15-33 \mathrm{~cm}$ tall, to $10 \mathrm{~cm}$ diameter pots filled with a mix of $1 / 3$ sand and $2 / 3$ standard garden soil (Selmaterra, Eric Schweizer AG, Thun, Switzerland). Plants used in the experiments were all in the vegetative stage.

On 10 July 2017, seven non-flowering individuals from each of seven native plant species (Table 1) were transplanted from the greenhouse to an experimental field near Magnago, Lombardy, Italy $\left(45.581^{\circ} \mathrm{N}, 8.793^{\circ} \mathrm{E}\right)$, which had a moderate density of $A$. artemisiifolia in the same field, high densities of $A$. artemisiifolia in adjacent fields $(\sim 150 \mathrm{~m}$ away), and high numbers of $O$. communa. Before transplanting, we mowed the experimental plot to ensure that the test plant species were not outcompeted by the resident vegetation, and we planted the experimental plants in a Latin-square design (seven rows with seven individuals per plant species), with $50 \mathrm{~cm}$ distances between the plants. Plants were watered twice a week to prevent desiccation, since some of these species normally grow in moister environments. We left three naturally occurring A. artemisiifolia plants in close proximity $(\sim 3 \mathrm{~m})$ to the experimental plot as an indicator for $O$. communa presence at the site. All other ragweed plants within a radius of $10 \mathrm{~m}$ around the experimental plot were repeatedly removed. At threeweekly intervals, we measured plant sizes, monitored the plants for the presence of $O$. communa and counted the number of egg batches, eggs per egg batch, larvae at the 1st, 2nd or 3rd instar stage, the number of pupae and adults, and estimated the percent leaf damage by $O$. communa.

\subsection{Laboratory experiments}

We conducted three replicates of two different laboratory experiments in 2017: (i) on non-target plant species exposed to adults of $O$. communa; and (ii) on non-target species exposed to newly-hatched larvae. We set up cages with six plants (one individual of $D$. graveolens, $P$. helveticum, $P$. britannicum and $P$. salicinum, and two C. nigrescens plants from different populations), and released either one adult per plant ( $30^{\prime}, 3$ per cage), or four larvae on each of the plants. The plants were kept in six plastic cat litter boxes $(35 \times 45 \times 15 \mathrm{~cm})$, each $10 \mathrm{~cm}$ away from the others, in a randomized design. Each box was placed in a netted cage $(60 \times 60 \times 60 \mathrm{~cm})$ in the quarantine facility of the University of Fribourg.

The adults and larvae used were reared in the quarantine facility 
from adults, eggs and pupae sourced in Northern Italy during 2013. To minimize inbreeding, the laboratory stocks were repeatedly supplemented by field populations taken from the same localities as the original laboratory population. The quarantine facility was kept at a day/ night temperature of $25 / 16{ }^{\circ} \mathrm{C}$, a photoperiod of L:D 14:10 hr and a relative humidity of $50 \pm 5 \%$. To ensure that freshly emerged adults ( $<$ seven days old) were used, pupae were collected one week before the experiments were started and kept in a separate container on an $A$. artemisiifolia plant. Freshly hatched larvae were taken from egg batches that were transferred on damp filter paper in Petri dishes one week before the experiments. Nine and 21 days after the start of the experiments we counted the number of egg batches, larvae, adults and recorded feeding damage. Eggs that were counted at day 9 were not counted a second time since eggs take $<9$ days to hatch. Larvae were likely double-counted, since only two larvae pupated during the experiment.

\subsection{Statistical analyses}

The data from the common garden experiment and the laboratory experiments were analysed by assessing the effects of plant species on the sum of the number of egg batches, larvae and adults observed during the experiment, as well as on percent leaf damage at the end of the experiment. For the experiments using adults of $O$. communa, we compared the sum of the number of egg batches and adults as well as the percent leaf damage by plant species at the end of the experiment. For the experiments using larvae, we assessed the effects of plant species on the sum of the number of larvae observed on the two sampling occasions, and on percent leaf damage at the end of the experiment. All comparisons were made using a Kruskal-Wallis test because of the nonnormal distributions of the data, and groups were identified post-hoc using a Fisher's least significant difference test. All analyses were conducted in $\mathrm{R}$ version 3.6.1, using the packages readxl (Wickham and Bryan, 2016), tidyr (Wickham and Henry, 2017), and agricolae (de Mendiburu, 2019). Figures were produced in ggplot2 (Wickham, 2009) and ggpubr (Kassambara, 2019).

\section{Results}

\subsection{Reported host range of O. Communa}

Previous no-choice host specificity tests with $O$. communa have revealed that it can complete its life-cycle on several plant species in the tribe Heliantheae (Bosio et al., 2014; Cao et al., 2011; Cardarelli et al., 2018; Futuyma, 1990; Hu and Meng, 2007; Lee et al., 2007; Lommen et al., 2017; Palmer and Goeden, 1991) (Supplementary Table 4). However, only a few test plant species from other tribes within the Asteraceae were included in these no-choice tests. On Dahlia pinnata Cav., the only species in the tribe Coreopsideae tested, six eggs were laid by $O$. communa, but neither adults nor larvae fed on the test plant (Palmer and Goeden, 1991). In the field, O. communa has primarily been recorded on species within the subtribe Ambrosiinae, including several Ambrosia and Xanthium species, Parthenium hysterophorus L., Iva axillaris Pursh., but also from Ratibida pinnata (Vent.) Barnhart (subtribe Rudbeckiinae) and Helianthus ciliaris DC. (subtribe Helianthinae) (Dernovici et al., 2006; Futuyma and McCafferty, 1990; Goeden and Ricker, 1985; McFadyen and McClay, 1981; Palmer and Goeden, 1991; Watanabe and Hirai, 2004). In earlier studies, sustained feeding by $O$. communa was only observed on plants in the tribes Ambrosiinae and Rudbeckiinae (Supplementary Table 4).

\subsection{Field survey}

During the 43 visits conducted in 2016, we did not find $O$. communa on any of the non-target species sampled (Supplementary Table 1). In 2017, we found three adults of $O$. communa feeding on a single plant of
B. cernua during one visit in Trezzo sull'Adda, Lombardy, Italy $(<1 \%$ leaf damage). The infested B. cernua plant was next to an A. artemisiifolia plant that had been completely defoliated and that was crowded with larvae and adults of $O$. communa (see Supplementary Plate 1 ). No attack of non-target species was observed during any of the other 42 visits made in 2017 (Supplementary Table 2), although we found $O$. communa feeding during all 13 visits to the five nearby $A$. artemisiifolia sites. During our sampling period, A. artemisiifolia was heavily damaged by abundant $O$. communa (Supplementary Table 1 ).

\subsection{Common garden field experiment}

On A. artemisiifolia plants, 3-150 m away from the common garden experiment, we found all stages of $O$. communa from the beginning of the experiment onwards. By mid-August, $O$. communa had almost completely ( $>95 \%$ ) defoliated the A. artemisiifolia plants surrounding the experimental site, and by early September 2017, all A. artemisiifolia plants were completely defoliated.

Adults of $O$. communa were found on test plant species included in the common garden experiment from mid-August onwards, i.e., 3 weeks after the experiment was set up (Supplementary Fig. 4). The number of adults $\left(\chi^{2}=23.37, \mathrm{p}<0.001, \mathrm{df}=6\right)$ and of larvae $\left(\chi^{2}=26.91, \mathrm{p}<0.001, \mathrm{df}=6\right)$ differed significantly between the plant species, but not the number of egg batches $\left(\chi^{2}=9.95, \mathrm{p}=0.126\right.$, $\mathrm{df}=6$ ). Egg batches (three egg batches with 9-20 eggs each) and larvae were only found on $D$. graveolens. The highest number of adults (32) per plant was found on C. nigrescens in late September 2017.

Overall leaf damage at the end of the experiment differed significantly among the plant species (Supplementary Fig. $4 ; \chi^{2}=33.60$, $\mathrm{p}<0.001, \mathrm{df}=6$ ). It was highest on $P$. helveticum (55-95\%), followed by $D$. graveolens $(10-80 \%)$ and C. nigrescens (10-35\%). Damage levels on the other test plant species were low and varied between 0 and $10 \%$ (Supplementary Fig. 4d).

\subsection{Laboratory experiments}

The non-target plant species used in the laboratory experiments (Supplementary Fig. 5) sustained significantly different degrees of leaf damage from the $O$. communa adults $\left(\chi^{2}=16.23, \mathrm{p}=0.006, \mathrm{df}=5\right)$ and differed marginally in the numbers of egg batches per plant species $\left(\chi^{2}=10.24, \mathrm{p}=0.069, \mathrm{df}=5\right)$, but not in the number of adults observed per plant $\left(\chi^{2}=7.51, \mathrm{p}=0.185, \mathrm{df}=5\right)$. Dittrichia graveolens sustained the highest amount of damage (ca. 20\%). We found eggs on all the plants except on $C$. nigrescens that came from a population originating near Pavia. Yet, egg hatching was only observed on $D$. graveolens; on all other plants, the eggs desiccated before the larvae could hatch.

Populations of $A$. artemisiifolia plants were exposed to females of $O$. communa from the same rearing colony, under identical experimental settings, one week before the experiments presented here; in these experiments, a mean $( \pm \mathrm{SE}$ ) of $0.8 \pm 0.04 \mathrm{egg}$ batches (or $22.8 \pm 1.4$ eggs) were laid per female and plant after 21 days (Litto et al., unpublished results). In the present experiment, we found a mean of only $0.3 \pm 0.07$ egg batches (or $2.9 \pm 0.8$ eggs) laid per female per plant; on $D$. graveolens, the mean was $0.7 \pm 0.19$ egg batches (or $5.2 \pm 1.7$ eggs) per female and plant after the same period of time.

When non-target plants were exposed to newly hatched larvae, the non-target plant species did not differ significantly in the total number of larvae recovered $\left(\chi^{2}=2.43, \mathrm{p}=0.787, \mathrm{df}=5\right)$, nor in the percentage of leaf damage sustained $\left(\chi^{2}=8.52, \mathrm{p}=0.130, \mathrm{df}=5\right)$ (Supplementary Fig. 6). Two larvae had pupated prior to the last sampling (after 21 days) and one larva had developed into an adult. In a control experiment with a similar set-up as the experiment using adult $O$. communa (see legend of Supplementary Fig. 7 for details), when $O$. communa adults were offered $A$. artemisiifolia, $P$. conyzae, $P$. helveticum, $P$. hirtum and $P$. spiraeifolium, we found many more eggs, larvae and 
adults on A. artemisiifolia than on any of the other plants, while leaf damage was more evenly distributed amongst the different plants (Supplementary Fig. 7).

\section{Discussion}

Hinz et al. (2019) defined degrees of non-target feeding/attack by biological control agents as follows. (i) 'Sustained' attack is where the biological control agents are able to fully develop and maintain populations on the non-target plant species, regardless of the presence or absence of the target weed. This is most likely to negatively influence plants at the population level (Blossey et al., 2018; Louda et al., 2005; Zimmermann et al., 2000). (ii) In contrast, 'collateral' or 'spill-over' non-target attack, usually occurs at high biological control agent densities resulting in the depletion of the target weed populations, which leads to opportunistic attacks on non-target plant species. In the latter cases the biological control agents are not able to maintain permanent populations on the non-target hosts and are thus unlikely to become a threat to non-target plants at the population level (Blossey et al., 2018). Hinz et al. (2019) further refined the latter terms: 'spill-over' non-target attack is on confamilial non-target species, which support full or partial development of the biological control agents; whereas 'collateral' nontarget attack is on taxonomically-unrelated non-target species on which the biological control agents cannot develop.

During our 2-year field surveys, we found O. communa feeding damage in only one of 85 instances on non-target species, while we observed feeding damage during all 13 surveys on nearby A. artemisiifolia populations. On one occasion, we observed three $O$. communa adults feeding on the leaves of a single $B$. cernua plant ( $<1 \%$ defoliation). The plant was directly adjacent to $A$. artemisiifolia plants that were heavily colonized by all developmental stages of $O$. communa (see Supplementary Plate 1). We consider this case to be a spill-over attack on $B$. cernua, but no-choice tests are required to assess to what extent $O$. communa can actually develop on this non-target species.

To ensure that all field surveyed populations of the non-target species were within the short-term dispersal range of $O$. communa, we chose survey locations close to $A$. artemisiifolia populations with $O$. communa present, often in high densities. Moreover, previous studies indicate that $O$. communa is a highly mobile insect species. For instance, we observed $O$. communa colonizing transplanted $A$. artemisiifolia plants that were at least $3 \mathrm{~km}$ away from and at an elevation 1,000 m higher than the nearest naturally occurring locations of $A$. artemisiifolia populations (Augustinus, unpublished results). Reports on the dispersal of O. communa after its introduction in Japan indicate that the beetle can spread at a rate of about $100 \mathrm{~km}$ per year (Moriya and Shiyake, 2001). Factors other than host plant suitability, including the micro-habitat of the surveyed populations, may explain why some of the non-target species were not colonized by $O$. communa. Nevertheless, the almost entire absence of non-target attack by $O$. communa on the surveyed populations of representatives of the tribes Coreopsideae and Inuleae agrees with the results from previously published field records (Futuyma and McCafferty, 1990; Palmer and Goeden, 1991; Hu and Meng, 2007) and indicates a low risk of sustained non-target attack on the non-target species included in the field survey.

The common-garden experiment was conducted in a location with large $O$. communa densities, and we observed feeding on non-target species, particularly on $D$. graveolens, $C$. nigrescens and $P$. helveticum, after the adjacent $A$. artemisiifolia plants had been completely defoliated. Except for $D$. graveolens, feeding was by adults only, indicating that most of the observed damage can be considered as a spill-over nontarget attack. The laboratory experiments provide additional evidence that $O$. communa can complete its life cycle on $D$. graveolens but as the latter species has extended its range and become an invasive element in the flora of western Europe, non-target attack by O. communa is not a concern. Nevertheless, we propose to monitor the level of the nontarget effect by $O$. communa on $D$. graveolens to assess whether sustained non-target attack by $O$. communa may also occur on a plant species outside of the tribe Heliantheae.

Our findings provide no evidence of sustained non-target attack on vulnerable and near-threatened native European plant species of the tribes Inuleae and Coreopsideae by $O$. communa. In cases of the coexistence of $A$. artemisiifolia with the rare Pentanema species, high densities of $O$. communa may incur considerable spill-over damage, as with adult feeding damage on $P$. helveticum in the common garden experiment. Spill-over attacks can cause conspicuous damage to individual plants, but there is no evidence that this type of non-target attack can lead to negative consequences at the population level for non-target species (Blossey et al., 2018; Hinz et al., 2019).

Centaurea nigrescens was also attacked by adult $O$. communa, but we did not find evidence that $O$. communa can develop on this non-target species which is confamilial with $A$. artemisiifolia, but in a different subfamily (Carduoideae). Adult feeding in this case is categorized as collateral damage, rather than as spill-over damage, but no-choice larval development and oviposition tests are needed to confirm this. If the host-range of $O$. communa is indeed restricted to the tribe Heliantheae, then the number of plant species that are potentially at risk in Europe is limited. The only native European species within the tribe Heliantheae is Ambrosia maritima L., which grows in a few places in Mediterranean Europe (Gerber et al., 2011; Orsenigo et al., 2017), and might be conspecific with $A$. artemisiifolia (Martin et al., 2018). The genus Pentanema (former Inula) (Gutiérrez-Larruscain et al., 2019), which includes several threatened or vulnerable native European species, was previously placed in the tribe Heliantheae, but is now placed in a separate tribe, Inuleae (http://tolweb.org/Heliantheae/22924).

In the common garden and the laboratory experiments reported in this study, most feeding damage on non-target species was caused by adults of $O$. communa. This is in line with earlier assessments in a field experiment in Northern Italy where $O$. communa individuals feeding on non-target plant species were predominantly adults, indicating a wider host range for adults compared to larvae (Cardarelli et al., 2018). Adult chrysomelids have often been shown to have a wider host range than the conspecific larval stages (e.g., Huang et al., 2011; Pemberton and Witkus, 2010; Wang et al., 2008). The highest number of $O$. communa adults was found on $C$. nigrescens, the test plant species phylogenetically most distantly related to $A$. artemisiifolia (Supplementary Fig. 2). In contrast, oviposition preferences roughly followed the phylogeny of the plant species included in the bioassays. As expected from other studies (Fowler and Witter, 1982; Cullen, 1990), the laboratory cage experiments on $O$. communa increased the range of host plants chosen for egg laying: we observed oviposition on all plant species in the laboratory experiment, but eggs hatched only on $D$. graveolens.

In summary, the results obtained from our field survey, the common garden and the laboratory experiments provide evidence that $O$. communa is unable to cause significant non-target damage on native European plant species. We found no evidence that rare and endangered plant species belonging to the closely related tribes Inuleae and Coreopsideae are likely to experience sustained attack by $O$. communa. Nevertheless, we suggest to continue monitoring populations of selected native plants, including $D$. graveolens and $P$. helveticum, for potential non-target attack by the recently introduced $O$. communa in Europe.

\section{Funding}

The study was funded by the e-COST Action FA1203 "Sustainable management of Ambrosia artemisiifolia in Europe (SMARTER)", the Swiss State Secretariat for Education, Research and Innovation (\#C14.0063 to U. Schaffner and \#C13.0146 to H. Müller-Schärer), the Pool de Recherche of the University of Fribourg (to H. Müller-Schärer and B. Augustinus), the Swiss Federal Office for the Environment (13.0098.KP/M323-0760 to H. Müller-Schärer), and the Federal Office of Agriculture (1062-62200 to to H. Müller-Schärer). Urs Schaffner was 
supported by CABI with core financial support from its member countries (see http://www.cabi.org/about-cabi/who-we-work-with/keydonors/).

\section{CRediT authorship contribution statement}

Benno Andreas Augustinus: Formal analysis, Investigation, Writing - original draft. Rodolfo Gentili: Investigation, Resources, Writing - review \& editing. David Horvath: Investigation. Ruhollah Naderi: Conceptualization, Methodology. Yan Sun: Formal analysis, Writing - review \& editing. Anne-Marth Truce Eleonoor Tournet: Investigation. Urs Schaffner: Conceptualization, Methodology, Writing review \& editing, Supervision. Heinz Müller-Schärer: Conceptualization, Methodology, Writing - review \& editing, Supervision.

\section{Declaration of Competing Interest}

The authors declare that they have no known competing financial interests or personal relationships that could have appeared to influence the work reported in this paper.

\section{Acknowledgements}

We thank Roberta Ceriani, Centro Flora Autoctona, Galbiate (Lecco), Federico Mangili, Bergamo, and Sofia Mangili, Museo Cantonale di Storia Naturale, Lugano, for locations of native and endemic plant populations. We are grateful to Nadav Nussbaum, Hagai Raz, Tessa Smith, Lise Berberat, Elisa Cardarelli and Suzanne Lommen in helping with the field survey, and to Joelle Romanens and Sinera Murati for contributing to the laboratory experiments. Roberta Ceriani, Centro Flora Autoctona, Catherine Lambelet, the Botanical Garden of Geneva, Albert - Dieter Stevens, Botanical Garden Berlin-Dahlem and Simona Strgulc Krajšek, University of Ljubliana provided seed material for the experiments.

\section{Appendix A. Supplementary data}

Supplementary data to this article can be found online at https:// doi.org/10.1016/j.biocontrol.2020.104356.

\section{References}

Augustinus, B.A., Guarino, M.F., Colombo, F., Citterio, S., Schaffner, U., Müller-Schärer, H., Gentili, R., 2015. Nuove Segnalazioni di Ambrosia artemisiifolia e Ophraella com muna in Valtellina (Alpi centrali, Lombardia). Nat. Bresc. 39, 235-238.

Augustinus, B., Sun, Y., Beuchat, C., Schaffner, U., Müller-Schärer, H., 2020. Predicting impact of a biocontrol agent: Integrating distribution modeling with climate-dependent vital rates. Ecol. Appl. 30 (1), e02003. https://doi.org/10.1002/eap.2003.

Blossey, B., Dávalos, A., Simmons, W., Ding, J., 2018. A proposal to use plant demographic data to assess potential weed biological agents impacts on non-target plant populations. Biocontrol 63, 461-473. https://doi.org/10.1007/s10526-018-9886-4.

Bonini, M., Šikoparija, B., Prentović, M., Cislaghi, G., Colombo, P., Testoni, C., Grewling, L., Lommen, S.T.E., Müller-Schärer, H., Smith, M., 2015a. Is the recent decrease in airborne Ambrosia pollen in the Milan area due to the accidental introduction of the ragweed leaf beetle Ophraella communa? Aerobiologia 31, 499-513. https://doi.org/ 10.1007/s10453-015-9380-8.

Bonini, M., Šikoparija, B., Prentović, M., Cislaghi, G., Colombo, P., Testoni, C., Grewling, L., Lommen, S.T.E., Müller-Schärer, H., Smith, M., 2015b. A follow-up study examining airborne Ambrosia pollen in the Milan area in 2014 in relation to the accidental introduction of the ragweed leaf beetle Ophraella communa. Aerobiologia 32, 371-374. https://doi.org/10.1007/s10453-015-9406-2.

Bornand, C., 2016. Rote Liste Gefässpflanzen: gefährdete Arten der Schweiz. BUWAL.

Bosio, G., Massobrio, V., Chersi, C., Scavarda, G., Clark, S., 2014. Spread of the ragweed leaf beetle, Ophraella communa LeSage, 1986 (Coleoptera Chrysomelidae), in Piedmont Region (northwestern Italy). Boll. Soc. Ent. Ital. 146, 17-30. https://doi org/10.4081/BollettinoSEI.2014.17.

Bullock, J., Chapman, D., Schafer, S., Roy, D., Girardello, M., Haynes, T., Beal, S., Wheeler, B., Dickie, I., Phang, Z., Tinch, R., 2012. Assessing and controlling the spread and the effects of common ragweed in Europe. Final Report to the European Commission, DG Environment.

Cao, Z., Meng, L., Li, B., 2011. Oviposition selection of Ophraella communa (Coleoptera:
Chrysomelidae) on common ragweed (Ambrosia artemisiifolia) in the field. Acta Entomol. Sin. 54, 1297-1304.

Cardarelli, E., Musacchio, A., Montagnani, C., Bogliani, G., Citterio, S., Gentili, R., 2018 Ambrosia artemisiifolia control in agricultural areas: effect of grassland seeding and herbivory by the exotic leaf beetle Ophraella communa. NeoBiota 38, 1-22. https:// doi.org/10.3897/neobiota.38.23562.

Cullen, J., 1990. Current problems in host-specificity screening. In: Proceedings of the VIIth International Symposium on the Biological Control of Weeds. pp. 27-36.

de Mendiburu, F., 2019. Package 'agricolae'. R Package, version 1.2-1.

Dernovici, S.A., Teshler, M.P., Watson, A.K., 2006. Is sunflower (Helianthus annus) at risk to damage from Ophraella communa, a natural enemy of common ragweed (Ambrosia artemisiifolia)? Biocontrol Sci. Techn. 16, 669-686. https://doi.org/10.1080/ 09583150600699820.

Essl, F., Biró, K., Brandes, D., Broenniman, O., Bullock, J.M., Chapman, D.S., Chauvel, B., Dullinger, S., Fumanal, B., Guisan, A., Karrer, G., Kazinczi, G., Kueffer, C., Laitung, B., Lavoie, C., Leitner, M., Mang, T., Moser, D., Müller-Schärere, H., Petitpierre, B., Richter, R., Schaffner, U., Smith, M., Starfinger, U., Vautard, R., Vogl, G., von der Lippe, M., Follak, S., 2015. Biological flora of the British Isles: Ambrosia artemisiifolia. J. Ecol. 103 (4), 1069-1098. https://doi.org/10.1111/1365-2745.12424.

Fand, B.B., Suroshe, S.S., Gautam, R., 2013. Fortuitous biological control of insect pests and weeds: a critical review. Bioscan 8, 1-10.

Fogliatto, S., Milan, M., De Palo, F., Vidotto, F., 2019. The effect of various after-ripening temperature regimens on the germination behaviour of Ambrosia artemisiifolia. Plant Biosystems 1, 1-8. https://doi.org/10.1080/11263504.2019.1578282.

Fowler, S.V., Paynter, Q., Dodd, S., Groenteman, R., 2012. How can ecologists help practitioners minimize non-target effects in weed biocontrol? J. Appl. Ecol. 49, 307-310. https://doi.org/10.1111/j.1365-2664.2011.02106.x.

Fowler, G.W., Witter, J.A., 1982. Accuracy and precision of insect density and impact estimates. Great Lakes Entomol. 15 (2), 5.

Futuyma, D.J., 1990. Observations on the taxonomy and natural history of Ophraella Wilcox (Coleoptera: Chrysomelidae), with a description of a new species. J. New York Entomol. 1, 163-186.

Futuyma, D.J., McCafferty, S.S., 1990. Phylogeny and the evolution of host plant associations in the leaf beetle genus Ophraella (Coleoptera, Chrysomelidae). Evolution 44 1885-1913. https://doi.org/10.1111/j.1558-5646.1990.tb04298.x.

Gentili, R., Gilardelli, F., Bona, E., Prosser, F., Selvaggi, A., Alessandrini, A., Martini, F. Nimis, P., Wilhalm, T., Adorni, M., 2017. Distribution map of Ambrosia artemisiifolia L. (Asteraceae) in Italy. Plant Biosystems 151, 381-386. https://doi.org/10.1080/ 11263504.2016.1176966.

Gerber, E., Schaffner, U., Gassmann, A., Hinz, H.L., Seier, M., Müller-Schärer, H., 2011. Prospects for biological control of Ambrosia artemisiifolia in Europe: learning from the past. Weed Res. 51 (6), 559-573. https://doi.org/10.1111/j.1365-3180.2011. 00879.x.

Goeden, R.D., Ricker, D.W., 1985. The life history of Ophraella notulata (F.) on western ragweed, Ambrosia psilostachya De Candolle, in southern California (Coleoptera: Chrysomelidae). Pan-Pac. Entomol. 61, 32-37.

Guo, J.-Y., Zhou, Z.-S., Zheng, X.-W., Chen, H.-S., Wan, F.-H., Luo, Y.-H., 2011. Control efficiency of leaf beetle, Ophraella communa, on the invasive common ragweed, Ambrosia artemisiifolia, at different growing stages. Biocontrol Sci. Techn. 21, 1049-1063. https://doi.org/10.1080/09583157.2011.603823.

Gutiérrez-Larruscain, D., Santos-Vicente, M., Montserrat Martinez-Ortega, M., Rico, E., 2019. Typification of 25 names in Inula (Inuleae, Asteraceae), and a new combination in Pentanema. Phytotaxa 395 (1), 17-26. https://doi.org/10.11646/phytotaxa.395. 1.2.

Hinz, H.L., Winston, R.L., Schwarzländer, M., 2019. How safe is weed biological control? A global review of direct nontarget attack. Q. Rev. Biol. 94, 1-27. https://doi.org/10. 1086/702340.

Hu, Y.-P., Meng, L., 2007. Potential impacts of alien herbivorous insect Ophraella communa (Coleoptera: Chrysomelidae) on non-target plants in mainland China. Chin J. Ecol. 26 (1), 56-60.

Huang, W., Wheeler, G.S., Purcell, M.F., Ding, J., 2011. The host range and impact of Bikasha collaris (Coleoptera: Chrysomelidae), a promising candidate agent for biological control of Chinese tallow, Triadica sebifera (Euphorbiaceae) in the United States. Biol. Control 56, 230-238. https://doi.org/10.1016/j.biocontrol.2010.11. 014.

Kassambara A., 2019. ggpubr:'ggplot2'Based Publication Ready Plots. R package version 2 .

Kazinczi, G., Béres, I., Novák, R., Karamán, J., 2009. Focusing again on common ragweed (Ambrosia artemisiifolia L.). Növényvédelem 45, 389-403.

Kazinczi, G., Béres, I., Novák, R., Bíró, K., Pathy, Z., 2008. Common ragweed (Ambrosia artemisiifolia): a review with special regards to the results in Hungary. Taxonomy, origin and distribution, morphology, life cycle and reproduction strategy. Herbologia 9, 55-91.

Kőmives, T., Béres, I., Reisinger, P., Lehoczky, E., Berke, J., Tamás, J., Páldy, A., Csornai, G., Nádor, G., Kardeván, P., Mikulás, J., 2006. New strategy of the integrated protection against common ragweed (Ambrosia artemisiifolia L.). Hung. Weed Res. Tech. 6, 5-50.

Lee, I.-Y., Park, J.-Y., Oh, S.-M., Park, J.-E., Kwon, O.-S., 2007. Selection of insects for potential biological control of Ambrosia trifida. Korean J. Weed Sci. 27 (4), 309-317.

Letunic, I., Bork, P., 2019. Interactive Tree Of Life (iTOL) v4: recent updates and new developments Nucleic acids res. 47(W1):W256-9. https://dpo/org/10.1093/nar/ gkz239.

Lombardia, Regione, 2010. Flora e piccolo fauna protette in Regione Lombardia. Centro Flora Autoctona della. Regione Lombardia (CFA).

Lommen, S.T., Hallmann, C.A., Jongejans, E., Chauvel, B., Leitsch-Vitalos, M., Aleksanyan, A., Tóth, P., Preda, C., Šćepanović, P., Onen, H., Tokarska-Guzik, B., 
2018. Explaining variability in the production of seed and allergenic pollen by invasive Ambrosia artemisiifolia across Europe. Biol. Invasions 20, 1475-1491. https:// doi.org/10.1007/s10530-017-1640-9.

Lommen, S.T.E., Jolidon, E.F., Sun, Y., Eduardo, J.I.B., Müller-Schärer, H., 2017. An early suitability assessment of two exotic Ophraella species (Coleoptera: Chrysomelidae) for biological control of invasive ragweed in Europe. Eur. J. Entomol. 114, 160-169. https://doi.org/10.14411/eje.2017.021.

Louda, S.M., Rand, T.A., Arnett, A.E., McClay, A.S., Shea, K., McEachern, A.K., 2005. Evaluation of ecological risk to populations of a threatened plant from an invasive biocontrol insect. Ecol. Appl. 15, 234-249. https://doi.org/10.1890/03-5212.

Martin, M.D., Quiroz-Claros, E., Brush, G.S., Zimmer, E.A., 2018. Herbarium collectionbased phylogenetics of the ragweeds (Ambrosia, Asteraceae). Mol. Phylogenet. Evol. 120, 335-341. https://doi.org/10.1016/j.ympev.2017.12.023.

McFadyen, R.E., McClay, A.S., 1981. Two new insects for the biological control of parthenium weed in Queensland. In: Wilson, B.J., Swarbrick, J.T. (Eds.), Proc AustralWeeds Conf. Weed Science Society of Queensland, Austra-lia, pp. 145-149.

Meng, L., Xu, J., Li, H., 2007. Dispersal and bionomics of the alien Ophraella communa in China mainland. Chin. J. Biol. Cont. 1, 5-10.

Montagnani, C., Gentili, R., Smith, M., Guarino, M.F., Citterio, S., 2017. The worldwide spread, success, and impact of ragweed (Ambrosia spp.). Crit. Rev. Plant. Sci. 36 (3), 139-178. https://doi.org/10.1080/07352689.2017.1360112.

Moriya, S., Shiyake, S., 2001. Spreading the distribution of an exotic ragweed beetle, Ophraella communa LeSage (Coleoptera: Chrysomelidae), in Japan. Jpn. J. Entomol. (New Series) 4, 99-102.

Müller-Schärer, H., Chauvel, B., Karrer, G., Kazinczi, G., Kudsk, P., Oude Lansik, A.G.J.M., Schaffner, U., Skjøth, C., Smith, M., Sun, Y., Vurro, M., de Weger, L., Lommen, S.T.E., 2018. Cross-fertilizing weed science and plant invasion science to improve efficient management: a European challenge. Basic Appl. Ecol. 33, 1-13. https://doi.org/10. 1016/j.baae.2018.08.003.

Müller-Schärer, H., Lommen, S.T.E., Rossinelli, M., Bonini, M., Boriani, M., Bosio, G., Schaffner, U., 2014. Ophraella communa, the ragweed leaf beetle, has successfully landed in Europe: fortunate coincidence or threat? Weed Res. 54, 109-119. https:// doi.org/10.1111/wre.12072.

Müller-Schärer, H., Schaffner, U., 2008. Classical biological control: exploiting enemy escape to manage plant invasions. Biol. Invasions 10, 859-874. https://doi.org/10. 1007/s10530-008-9238-x.

Mouttet, R., Augustinus, B.A., Bonini, M., Chauvel, B., Desneux, N., Gachet, E., Le Bourgeois, T., Müller-Schärer, H., Thibaudon, M., Schaffner, U., 2018. Estimating economic benefits of biological control of Ambrosia artemisiifolia by Ophraella communa in southeastern France. Basic Appl. Ecol. 33, 14-24. https://doi.org/10.1016/j. baae 2018.08 .002 .

Müller-Schärer, H., Schaffner, U., and the COST-SMARTER Task Force Ophraella, 2017. COST-SMARTER and risk assessment of Ophraella communa. Not. Soc. Bot. Ital. 1, 105-107.

Orsenigo, S., Astuti, G., Bartolucci, F., Citterio, S., Conti, F., Becerra, J.A.G., Gentili, R., del Galdo, G.G., Jiménez-Martínez, J.F., Karrer, G., Lahora, A., 2017. Global and Regional IUCN Red List Assessments: 3. Ital. Bot. 3, 83-98. https://doi.org/10.3897/ italianbotanist. 3.13303

Palmer, W.A., Goeden, R.D., 1991. The host range of Opheraella communa Lesage (Coleoptera: Chrysomelidae). The Coleopt. Bull. 45, 115-120.

Pemberton, R.W., Witkus, G.L., 2010. Laboratory host range testing of Lilioceris sp. nea impressa (Coleoptera: Chrysomelidae) - a potential biological control agent of air potato, Dioscorea bulbifera (Dioscoreaceae). Biocontrol Sci. Tech. 20, 567-587. https://doi.org/10.1080/09583150903531332.

Reeder, R., Bacon, E., Caiden, M., Bullock, R., González-Moreno, P., 2018. Effect of population density of the Azolla weevil (Stenopelmus rufinasus) on the surface cover of the water fern (Azolla filiculoides) in the UK. Biocontrol 63, 185-192. https://doi.org/ 10.1007/s10526-017-9861-5.

Schaffner, U., Smith, L., Cristofaro, M., 2018. A review of open-field host range testing to evaluate non-target use by herbivorous biological control candidates. Biocontrol 63 , 405-416. https://doi.org/10.1007/s10526-018-9875-7.

Schaffner, U., Steinbach, S., Sun, Y., Skjøth, C., de Weger, L.A., Lommen, S.T.E., Augustinus, B.A., Bonini, M., Karrer, G., Šikoparija, B., Thibaudon, M., MüllerSchärer, H., 2020. Biological weed control to relieve millions of allergy sufferers in Europe. Nat. Commun. 11 (1), 1745. https://doi.org/10.1038/s41467-020-15586-1.
Seebens, H., Blackburn, T.M., Dyer, E.E., Genovesi, P., Hulme, P.E., Jeschke, J.M., Pagad, S., Pyšek, P., Winter, M., Arianoutsou, M., Bacher, S., 2017. No saturation in the accumulation of alien species worldwide. Nat. Commun. 8 (1), 1-9. https://doi.org/ 10.1038/ncomms14435.

Shaw, R.H., Ellison, C.A., Marchante, H., Pratt, C.F., Schaffner, U., Sforza, R.F., Deltoro, V., 2018. Weed biological control in the European Union: from serendipity to strategy. Biocontrol 63, 333-347. https://doi.org/10.1007/s10526-017-9844-6.

Shaw, R., Schaffner, U., Marchante, E., 2016. The regulation of biological control of weeds in Europe-an evolving landscape. EPPO Bulletin 46, 254-258. https://doi.org/ 10.1111/epp.12308.

Skjøth, C.A., Sun, Y., Karrer, G., Sikoparija, B., Smith, M., Schaffner, U., Müller-Schärer, H., 2019. Predicting abundances of invasive ragweed across Europe using a "topdown" approach. Sci. Total Environ. 686, 212-222. https://doi.org/10.1016/j. scitotenv.2019.05.215.

Sohn, J., An, S., Lee, J., Park, K., 2002. Notes on exotic species, Ophraella communa LeSage (Coleoptera: Chrysomelidae) in Korea. Hanguk Ungyong Konchung Hakhoe Chi 41, $145-150$.

Sun, Y., Zhou, Z., Wang, R., Müller-Schärer, H., 2017. Biological control opportunities of ragweed are predicted to decrease with climate change in East Asia. Biodivers. Sci. 25, 1285-1294. https://doi.org/10.17520/biods.2017096.

Takizawa, H., 1999. Invading insect, Ophraella communa LeSage, 1986 - range extension and life history in Kanto district. Japan Gek-kan-mushi 338, 26-31.

Thibaudon, M., Hamberger, C., Guilloux, L., Massot, R., 2010. Ragweed pollen in France: Origin, diffusion, exposure. Eur. Ann. Allergy Clin. Immunol. 42, 209-215.

Toole, E.H., Brown, E., 1946. Final results of the Duvel buried seed experiment. J. Agric. Res. 72, 201-210.

Vilà, M., Espinar, J.L., Hejda, M., Hulme, P.E., Jarošík, V., Maron, J.L., Pergl, J., Schaffner, U., Sun, Y., Pyšek, P., 2011. Ecological impacts of invasive alien plants: a meta-analysis of their effects on species, communities and ecosystems. Ecol. Lett. 14, 702-708. https://doi.org/10.1111/j.1461-0248.2011.01628.x.

Wang, C., Chiang, M., 1998. New record of a fastidious chrysomelid, Ophraella communa LeSage (Coleoptera: Chrysomelidae), in Taiwan. Plant Prot. Bull. (Taipei) 40, 185-188.

Wang, Y., Ding, J., Zhang, G., 2008. Gallerucida bifasciata (Coleoptera: Chrysomelidae), a potential biological control agent for Japanese knotweed (Fallopia japonica). Biocontrol Sci. Tech. 18, 59-74. https://doi.org/10.1080/09583150701742453.

Wapshere, A., 1974. A strategy for evaluating the safety of organisms for biological weed control. Ann. Appl. Biol. 77, 201-211. https://doi.org/10.1111/j.1744-7348.1974. tb06886.x.

Watanabe, M., Hirai, Y., 2004. Host-use pattern of the ragweed beetle Ophraella communa LeSage (Coleoptera: Chrysomelidae) for overwintering and reproduction in Tsukuba. Appl. Entomol. Zool. (Jpn.) 39, 249-254. https://doi.org/10.1303/aez.2004.249.

Wickham, H., 2009. ggplot2: Elegant Graphics for Data Analysis. Springer Publishing Company, Incorporated.

Wickham, H., Bryan, J., 2016. readxl: Read excel files R package version 1.1.

Wickham, H., Henry, L., 2017. Tidyr: Easily tidy data with'spread'and'gather'functions R package version 6.1.

Zadravec, M., Horvatić, B., Prpić, P., 2019. The Balkans invaded-first record of Ophraella communa LeSage, 1986 (Coleoptera: Chrysomelidae) in Croatia. Bioinvasions Rec. 8, 521-529. https://doi.org/10.3391/bir.2019.8.3.07.

Zhou, Z.-S., Guo, J.-Y., Zheng, X.-W., Luo, M., Chen, H.-S., Wan, F.-H., 2011. Reevaluation of biosecurity of Ophraella communa against sunflower (Helianthus annuus). Biocontrol Sci. Tech. 21, 1147-1160. https://doi.org/10.1080/09583157.2011. 606559.

Zhou, Z.-S., Guo, J.-Y., Zheng, X.-W., Luo, M., Chen, H.-S., Wan, F.-H., 2014. Control of the invasive weed Ambrosia artemisiifolia with Ophraella communa and Epiblema strenuana. Biocontrol Sci. Tech. 24, 950-964. https://doi.org/10.1080/09583157. 2014.897305.

Zhou, Z., Wan, F., Guo, J., 2017. Common ragweed Ambrosia artemisiifolia. In: Wan, F., Jiang, M., Zhan, A. (Eds.), Biological Invasions and Its Management in China. Springer, pp. 99-109. https://doi.org/10.1007/978-981-10-3427-5_7.

Zimmermann, H.G., Moran, V.C., Hoffmann, J.H., 2000. The renowned cactus moth, Cactoblastis cactorum: its natural history and threat to native Opuntia floras in Mexico and the United States of America. Divers. Distrib. 6, 259-269. https://doi.org/10. 1046/j.1472-4642.2000.00088.x. 